\section{Glucagon-like peptide-1(7-36) amide and glycogen synthesis in the liver}

\section{Dear Sir,}

Glucagon like-peptide-1 (GLP-1) (7-36) amide/(7-37) is an intestinal post-translational product of proglucagon and stimulates insulin secretion in a glucose-dependent manner [1]. In addition, GLP-1 (7-36) amide/(7-37) suppresses glucagon secretion and stimulates somatostatin secretion [2]. As for its extrapancreatic effects, it has been suggested that GLP-1 (736) amide directly promotes glucose uptake in human in vivo studies $[3,4]$. GLP-1 receptor gene is expressed with relatively high abundance in the pancreatic islet, lung and stomach, and also expressed at a lower level in the brain, liver, skeletal muscle and kidney [5]. However, our previous study demonstrated that GLP-1 (7-37) does not affect glucose output from the perfused rat liver [6], and it did not block any of the actions of glucagon in isolated rat hepatocytes [7]. Valverde et al. [8] however, recently demonstrated that both GLP-1 (7-36) amide and GLP-1 (1-36) amide stimulate the incorporation of $\mathrm{D}-\left[\mathrm{U}-{ }^{14} \mathrm{C}\right]$ glucose into glycogen in isolated rat hepatocytes with a higher potency than insulin. We therefore examined the effect of GLP-1 (7-36) amide on glycogen

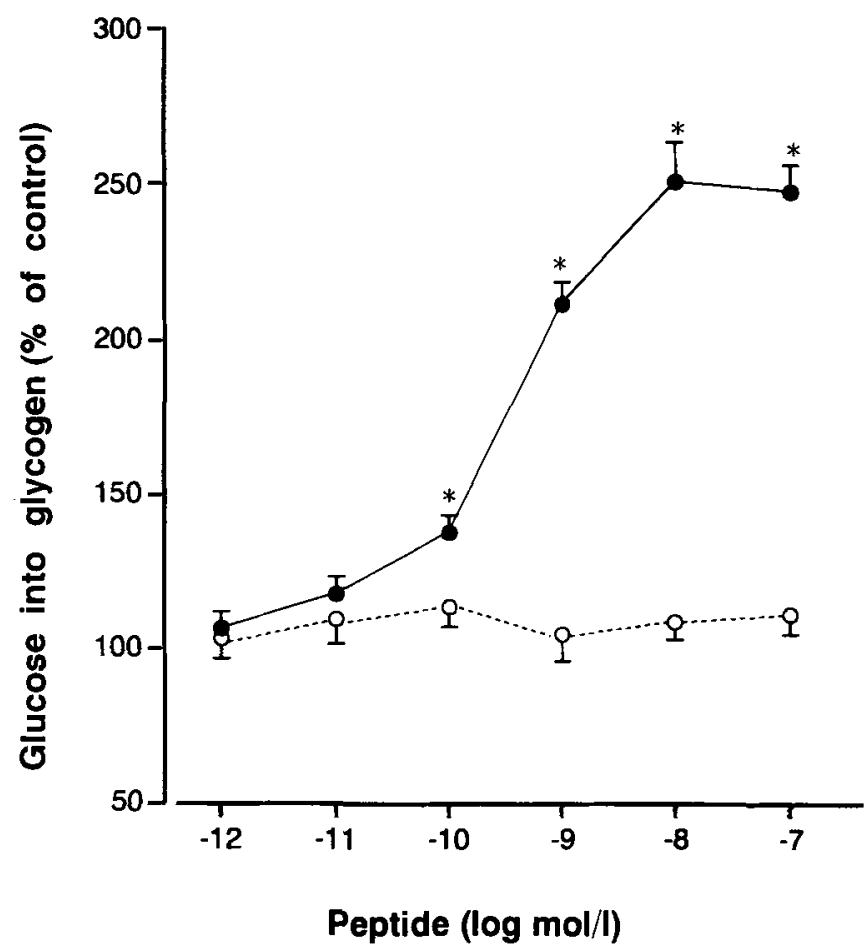

Fig.1. The rates of incorporation of $\mathrm{D}-\left[\mathrm{U}-{ }^{14} \mathrm{C}\right]$ glucose into glycogen in isolated rat hepatocytes during a $3 \mathrm{~h}$ incubation in the presence of GLP-1 (7-36) amide $(\mathrm{O} n=11)$ or insulin ( $n=11$ ) at the concentrations ranging from $10^{-12}$ to $10^{-7} \mathrm{~mol} / \mathrm{l}$. Data are expressed as percentage refer to the control experiment conducted with the incubation of hepatocytes obtained from the same individual rat in the absence of GLP$1(7-36)$ amide or insulin. ${ }^{*} p<0.05$ vs $10^{-12} \mathrm{~mol} / 1 \mathrm{insulin}$

Corresponding author: Dr. K. Yamashita, Department of Internal Medicine, Institute of Clinical Medicine, University of Tsukuba, Tennodai 1-1-1, Tsukuba, Ibaraki-ken, 305, Japan synthesis in rat hepatocytes using the same methods as those of Valverde et al. [8] except for the preincubation periods of isolated hepatocytes.

In our study, insulin increased the rate of incorporation of $\mathrm{D}-\left[\mathrm{U}-{ }^{14} \mathrm{C}\right]$ glucose into hepatocyte glycogen in dose-dependent manner at concentrations between $10^{-10}$ and $10^{-8} \mathrm{~mol} / 1$ (Fig. 1 ). The maximal increment of the rate of glucose incorporation by insulin was $250.8 \pm 13.1 \%$ of the control experiment (addition of vehicle) at $10^{-8} \mathrm{~mol} / \mathrm{l}$. On the other hand, GLP-1 (7-36) amide did not affect the rate of glucose incorporation at concentrations ranging from $10^{-12} \mathrm{~mol} / / \mathrm{l}$ to $10^{-7} \mathrm{~mol} / 1$ (Fig. 1). Glucagon at $10^{-9} \mathrm{~mol} / \mathrm{l}$ suppressed the incorporation of glucose into glycogen $(52.3 \pm 6.4 \%$ of control) and the combination of $10^{-9} \mathrm{~mol} / \mathrm{l}$ insulin and $10^{-9} \mathrm{~mol} / \mathrm{l}$ glucagon inhibited each action (100.4 $\pm 10.1 \%$ of control). The rate of incorporation with both $10^{-8} \mathrm{~mol} / \mathrm{l} \mathrm{GLP}-1$ (7-36) amide and $10^{-9} \mathrm{~mol} / \mathrm{l}$ glucagon tended to decrease less than with $10^{-8} \mathrm{~mol} / \mathrm{l}$ glucagon alone $(43.3 \pm 8.6 \%$ of control vs $52.3 \pm 6.4 \%, p<0.1)$.

We could not demonstrate any insulin-like effects of GLP1 (7-36) amide on glucose metabolism in isolated rat hepatocytes, although insulin stimulated the glucose incorporation more remarkably than in the experiments by Valverde et al. [8]. It was rather suggested that GLP-1 (7-36) amide might suppress the glucose incorporation into glycogen in cooperation with glucagon. A marked difference in experimental methods is the culture time of the cells; they used the cells immediately after the isolation, but we incubated the cells for $24 \mathrm{~h}$. We therefore also performed the study using freshly isolated hepatocytes. The results, however, were the same (data not shown). Although a potent glycogenic effect of GLP-1 (7-36) amide was also reported in rat skeletal muscle from the same laboratory [9], the results were not reproducible [10]. Considering this irreproducibility and previous findings $[6,7]$, our present findings should indicate that GLP-1 (7-36) amide has no potent effects on glucose metabolism in the liver.

Yours sincerely,

Y. Nakagawa, K. Kawai, H. Suzuki, S. Ohashi, K. Yamashita

Acknowledgements. The authors thank Dr. M. Odawara, Institute of Clinical Medicine, University of Tsukuba for his critical revision of this paper.

\section{References}

1. Kreymann B, Ghatei MA, Williams G, Bloom SR (1987) Glucagon-like peptide-1 7-36: a physiological incretin in man. Lancet II: $1300-1303$

2. Kawai K, Suzuki S, Ohashi S et al. (1989) Comparison of the effect of glucagon-like peptide-1 -(1-37) and -(7-37) and glucagon on islet hormone release from isolated perfused canine and rat pancreases. Endocrinology 124: 17681773

3. Gutniack M, Ørskov C, Holst JJ, Ahren B, Efendic S (1992) Antidiabetogenic effect of glucagon-like peptide-1 (7-36) amide in normal subjects and patients with diabetes mellitus. N Engl J Med 326: 1316-1322

4. D'Alessio DA, Kahn SE, Leusner CR, Ensinck JW (1994) Glucagon-like peptide- 1 enhances glucose tolerance both by stimulation of insulin release and by increasing insulinindependent glucose disposal. J Clin Invest 93: 2263-2266

5. Wheeler MB, Lu M, Dillon JS, Leng XH, Chen C, Boyd AE III (1993) Functional expression of the rat glucagonlike peptide-1 receptor, evidence for coupling to both 
adenylyl cyclase and phospholipase-C. Endocrinology 133 : $57-62$

6. Murayama Y, Kawai K, Suzuki S, Ohashi S, Yamashita K (1990) Glucagon-like peptide-1 (7-37) does not stimulate either hepatic glycogenolysis or ketogenesis. Endocrinol Japon 37: 293-297

7. Blackmore PF, Mojsov S, Exton JH, Habener JF (1991) Absence of insulinotropic glucagon-like peptide-1 (7-37) receptor on isolated rat liver hepatocytes. FEBS Lett 283 : $7-10$
8. Valverde I, Morales M, Clemente F et al. (1994) Glucagonlike peptide-1: a potent glycogenic hormone. FEBS Lett 349: 313-316

9. Villanueva-Peñacarrillo ML, Alcántara AI, Clemente F, Delgado E, Valverde I (1994) Potent glycogenic effect of GLP-1 (7-36) amide in rat skeletal muscle. Diabetologia 37: $1163-1166$

10. Fürnsinn C, Ebner K, Waldhäusl W (1995) Failure of GLP1 (7-36) amide to affect glycogenesis in rat skeletal muscle. Diabetologia 38: 864-867

\section{Diabetes mellitus and Alzheimer's disease}

\section{Dear Sir}

Recently in a letter in Diabetologia [1] it was suggested that "the occurrence of AGE (advanced glycation end products) in both diabetes and Alzheimer's disease might lead one to predict a higher-than-expected incidence of concurrent diabetes and Alzheimer's disease. However, predictions of diabetes and concurrent Alzheimer's disease unfortunately must await epidemiological analyses ...." "Conversely, life-long glycation may result in compensations, leading instead to discordance of Alzheimer's disease and diabetes".

The Umeå Dementia Research Group reported a population-based study of 839 patients with various dementia diagnoses of whom 457 were classified as multi-infarct dementia (MID), 317 as dementia of Alzheimer type (SDAT) and 65 as confusional states [2]. Sixty patients were found to have diabetes, none in the SDAT group, but 55 in the MID group and 5 in the group of confusional states. Oral glucose tolerance tests were performed in patients not known to have diabetes and

Corresponding author: Dr. F. Lithner, Department of Medicine, University Hospital, S-90185 Umeå, Sweden compared in patients with SDAT, MID, cerebrovascular diseases, hospitalized control patients and healthy elderly patients. Fasting blood glucose levels were lower and the areas under the oral glucose tolerance curves smaller in the SDAT group compared with the cerebrovascular and the hospitalized control groups. SDAT patients had higher insulin levels than the healthy elderly group. Our findings may be in accordance with the second suggestion mentioned above. However, initially low concentrations of brain transmitters are further negatively influenced by the lack of an important source of energy or perhaps by the lack of a metabolite necessary for the production of transmitters.

Yours sincerely,

F. Lithner

\section{References}

1. Smith MA, Sayre LM, Perry G (1996) Diabetes and Alzheimer's disease: glycation as a biochemical link. Diabetologia 39: 247 (Letter)

2. Bucht G, Adolfsson R, Lithner F, Winblad B (1983) Changes in blood glucose and insulin secretion in patients with senile dementia of Alzheimer type. Acta Med Scand 213: 387-392

\section{Elevated circulating adhesion molecules in NIDDM - potential mediators in diabetic macroangiopathy}

\section{Dear Sir}

Increased expression of endothelial adhesion molecules (AMs) may have a potential role in accelerated diabetic macroangiopathy [1], possibly stimulated by oxidized low-density lipoproteins (LDL) and free radicals derived from glucose auto-oxidation [2], since "classical" risk factors including hyperlipidaemia, hypertension and obesity do not completely account for the increased incidence of atherosclerosis in diabetes [3]. Such adhesion molecules are involved in chemotaxis of cir-

Corresponding author: Dr. P.Fasching, Department of Medicine III, Division of Endocrinology and Metabolism, University of Vienna, AKH, Währinger Gürtel 18-20, A-1090 Vienna, Austria culating monocytes and binding of leukocytes and platelets to the endothelium. This leukocyte recruitment is considered an initial step in development of atherosclerotic lesions [4]. Raised plasma concentrations of soluble circulating adhesion molecules occurring after proteolytic cleavage of the extracellular domain may indicate endothelial activation and increased interaction of leukocytes and platelets with the endothelium as recently shown for a small number of non-insulin-dependent diabetic (NIDDM) patients $(n=13)$ [5] and diabetic patients not requiring insulin treatment [6].

In a cross-sectional study, we therefore analysed serum concentrations of circulating intercellular adhesion molecule-1 (cICAM-1), vascular cell adhesion molecule-1 (cVCAM-1), and endothelial leukocyte adhesion molecule-1 (cELAM$1=$ E-selectin) in a large group of metabolically stable NIDDM patients $(n=159)$ and age-matched healthy subjects $(n=71)$ with no clinically manifest infections and who were not receiving any anti-inflammatory medication. NIDDM patients were treated either by diet alone, with additional sulphonylurea or biguanides $(n=80)$, or by conventional insulin therapy $(n=79)$ with two daily subcutaneous insulin injections (clinical data are given in Table 1 ). 